\title{
Effect of a specific aromatase inhibitor on oestradiol secretion by porcine corpora lutea at various stages of the luteal phase
}

\author{
EL Gregoraszczuk, K Oblonczyk \\ Laboratory of Animal Endocrinology and Tissue Culture, Department of Animal Physiology, \\ Institute of Zoology, Jagiellonian University, Cracow, Poland
}

(Received 21 February 1995; accepted 12 December 1995)

\begin{abstract}
Summary - The present study was undertaken to investigate the aromatization capability of pig corpora lutea at different stages of the luteal phase using the nonsteroidal aromatase inhibitor CGS 16949A. Luteal cells were collected during early (0-2 days after ovulation), mid- (7-10 days after ovulation) and late (13-16 days after ovulation) luteal phase. Cells were incubated either with or without $10^{-7} \mathrm{MT}$ (testosterone-supplemented culture). Six hours after starting the cultures, $0.1,0.5$ or $1.0 \mu \mathrm{M}$ aromatase inhibitor was added to both culture types for the next $12 \mathrm{~h}$ period. Addition of the aromatase inhibitor to the luteal cells isolated during the early luteal phase had no effect on basal and testosterone-supplemented oestradiol secretion. The aromatase inhibitor added to cells isolated during the mid- and late luteal phase, however, caused a significant decrease in the basal and testosteronestimulated secretion of oestradiol. This supports the hypothesis that luteal cells from these stages have active aromatase. The highest aromatization potential was observed in regressing corpora lutea. Oestradiol secreted by the regressing corpora lutea could play an active role in the regulation of oestrus cycle and could have a possible endocrine influence on gonadotropin secretion, a paracrine action on follicular growth or an autocrine influence on the luteal activity.
\end{abstract}

aromatase / CGS 16949A / oestradiol secretion / pig luteal / cells

Résumé - Effets d'un inhibiteur de l'aromatase sur la sécrétion d'œstradiol des corps jaunes de truie à différents stades de la phase lutéale. L'objectif de ce travail est de définir l'aptitude à aromatiser du corps jaune de truie à différents moments de la phase lutéale après l'application de l'inhibiteur nonstéroïdogène de l'aromatase CGS 16949A. Des cellules lutéales ont été isolées pendant la phase lutéale précoce ( 0 à 2 jours après ovulation), médiane ( 7 à 10 jours après ovulation) et tardive (13 à 16 jours après ovulation). Les cellules ont été incubées en ajoutant ou non $10^{-7} \mathrm{MT}$ (= cultures stimulées à la testostérone). Six heures après le début de culture, $0,1,0,5$ ou 1,0 $\mu \mathrm{M}$ d'inhibiteur de l'aromatase ont été ajoutés pour les 12 heures suivantes. L'inhibiteur de l'aromatase ajouté à la culture des cellules lutéales isolées pendant la phase lutéale précoce n'affecte pas la sécrétion d'cestradiol basale ou en présence de testostérone. L'inhibiteur de l'aromatase ajouté à la culture des cellules isolées aux stades médian et tardif de la phase lutéale entraîne une baisse de la sécrétion de l'œestradiol 
basale et de celle mesurée en présence de testostérone. Ces résultats montrent que le corps jaune porcin adulte présente une aromatase active. C'est le corps jaune en régression qui manifeste la plus grande aptitude à aromatiser. L'œestradiol sécrété pendant la régression du corps jaune pourrait jouer un rôle important dans la régulation du cycle œestral grâce à une action endocrinienne sur les niveaux de gonadotrophines, une action paracrine sur la croissance des follicules ou encore une action autocrine sur les fonctions lutéales.

aromatase / CGS 16949A / sécrétion d'œestradiol / corps jaune / truie

\section{INTRODUCTION}

The conversion of androgens (testosterone, androstenedione and 16-hydroxyandrostenedione) to oestrogens is mediated by aromatase, a cytochrome P450-dependent enzyme. During reproductive life, aromatase is mainly found in the ovaries and placenta. In pigs, theca cells synthesize androgens which are then aromatized by granulosa cells (Bjersing, 1967; Stoklosowa et al, 1982). Corpora lutea originate from both kinds of cells and are able to produce oestrogens (Rodway et al, 1975; Gregoraszczuk, 1983, 1992; Przala et al, 1984). The analysis of the oestradiol content in homogenates and suspensions from luteal tissues prior to culture strongly suggests that there is an increase in oestradiol production as the luteal phase progresses (Gregoraszczuk, 1992). The oestradiol-to-androgen ratio changes during the development and regression of the corpora lutea. An increase in the oestrogen-to-androgen ratio suggests an increase in aromatase activity towards the end of the luteal phase (Gregoraszczuk, 1992). The aromatization ability of the corpora lutea at different stages of the luteal phase, however, has not been measured until now. The aim of the present study was, therefore, to assess the involvement of aromatase in the oestradiol secretion by porcine corpora lutea and to detect variations in the aromatization capability during the luteal phase. For this purpose, oestradiol secretion by luteal cells was measured with and without treatment with an aromatase inhibitor. Luteal cells were harvested from the corpora lutea collected during early, mid- and late luteal phase.

\section{MATERIALS AND METHODS}

\section{Tissue preparation}

Pig ovaries were collected from a local butcher. Only ovaries containing large $(0.8-1.2 \mathrm{~cm}$ external diameter) vascular follicles and either no corpora lutea or only corpora albicantia were selected as the source of granulosa cells. Luteal cells were isolated from corpora lutea and were then classified according to the Gregoraszczuk criteria (1992): 1) newly formed corpora lutea (0-2 days after ovulation) which were dark red in colour and contained blood clots in the inner cavities were classified as early luteal phase corpora lutea (ELP); 2) soft, large corpora lutea, pink in colour with distinct blood vessels at their surface and with their inner cavity filled with luteal tissue (7-10 days after ovulation) were classified as mid-luteal phase corpora lutea (MLP); and 3) corpora lutea that were hard in consistency, pale pink to yellowish-white in colour with receding blood vessels (13-16 days after ovulation) were classified as late luteal phase corpora lutea (LLP).

\section{Tissue culture}

Granulosa cells were harvested according to Stoklosowa et al (1982) and luteal cells by the author's own technique (Gregoraszczuk, 1983). Luteal tissue was first minced mechanically and then trypsinized in $0.25 \%$ solution three times for $10 \mathrm{~min}$ at $37^{\circ} \mathrm{C}$ under continuous stirring. Cells were suspended in M199 medium supplemented 
with $10 \%$ of calf serum at a concentration of $1 x$ $10^{6}$ granulosa cells $/ \mathrm{mL}$ and $3.5-5.0 \times 10^{5}$ luteal cells/ $/ \mathrm{mL}$ and incubated in multiwell plates (Corning) in a humidified atmosphere of $5 \% \mathrm{CO}_{2}$.

Cell viability was determined by the trypan blue exclusion test and was $95 \%$ for granulosa cells and $80-85 \%$ for luteal cells.

Cells were incubated either with or without $10^{-7} \mathrm{M}$ testosterone (testosterone-supplemented cultures). Six hours after starting the cultures, $0.1,0.5$ or $1.0 \mu \mathrm{M}$ aromatase inhibitor CGS $169 \mathrm{~A}$ was added to both culture types (Steele et al, 1987). Twelve hours later, all cultures were terminated. Cultures were incubated in quadriplicate in each of the four experiments.

\section{Steroid analysis}

Oestradiol was detected in the medium by radioimmunoassay (Stoklosowa et al, 1982). A highly specific antibody directed against oestradiol-17 $\beta$-6-oxime-BSA antigen was raised in rabbits. It gave negligible cross-reactions with oestrone $(0.8 \%)$, oestriol $(0.8 \%)$, and 16-ketooestriol-17 $(1.0 \%)$. All the other tested steroids showed a cross-reaction level lower than $0.001 \%$. $[2,4,6,7,16,17-3 \mathrm{H}]$ oestradiol (Radiochemical Centre, Amersham, UK), was used as the tracer $(140 \mathrm{Ci} / \mathrm{mmol})$. The limit of detection of the assay was $5 \mathrm{pg} / \mathrm{mL}$. The coefficients of variation within and between the assays were less than 7.5 and $8.5 \%$ respectively.

\section{Statistical analysis}

Differences between stages and treatments (with or without testosterone; without testosterone and with various levels of the aromatase inhibitor; with testosterone and with various levels of the aromatase inhibitor) were compared by analysis of variance and Duncan's new multiple range test.

\section{Reagents}

The M199 medium, calf serum, trypsin $(0.25 \%$ solution in calcium- and magnesium-free PBS) were products of the Laboratory of Sera and Vaccines (Lublin, Poland). Testosterone was pur- chased from Sigma (USA) and the aromatase inhibitor CGS 16949A 4,5,6,7,8-tetrahydroimidazo [1,4-alpydrin-5-yl]benzonitrile) monohydrochloride from Ciba-Geigy AG (Basel, Switzerland).

\section{RESULTS}

\section{Granulosa cells (G)}

The aromatase inhibitor caused a dosedependent decrease in both basal oestradiol secretion $(18.6,19.6,31.4,45.2 \mathrm{pg}$ oestradiol / $10^{5}$ cells for $1.0,0.5,0.1,0.0$ $\mu \mathrm{M}$ aromatase inhibitor, respectively) (fig 1) and testosterone-stimulated secretion (81.2, 93.7, $107.5,131.5 \mathrm{pg}$ oestradiol / $10^{5}$ cells for $1.0,0.5,0.1,0 \mu \mathrm{M}$ aromatase inhibitor, respectively) (fig 2).

\section{Luteal cells (CL)}

\section{Early luteal phase}

Adding testosterone to the culture medium did not influence the ELP oestradiol secretion (fig 3). Adding aromatase inhibitor affected neither the basal nor the testosterone-stimulated oestradiol secretion (figs 1 and 2).

\section{Mid-luteal phase}

Adding testosterone to the culture of cells harvested at this stage caused a significant increase in their oestradiol secretion (fig 3). Basal oestradiol secretion was decreased by all doses of the inhibitor $(40.7,45.0,51.4$, $67.1 \mathrm{pg}$ oestradiol $/ 10^{5}$ cells for $1.0,0.5,0.1$, $0 \mu \mathrm{M}$ aromatase inhibitor, respectively) (fig 1). A dose-dependent decrease in oestradiol secretion in testosterone-supplemented cultures was observed with the aromatase inhibitor $(72.5,87.5,126.2,131.5 \mathrm{pg}$ oestradiol / $10^{5}$ cells for $1.0,0.5,0.1,0 \mu \mathrm{M}$ aromatase inhibitor, respectively) (fig 2). 


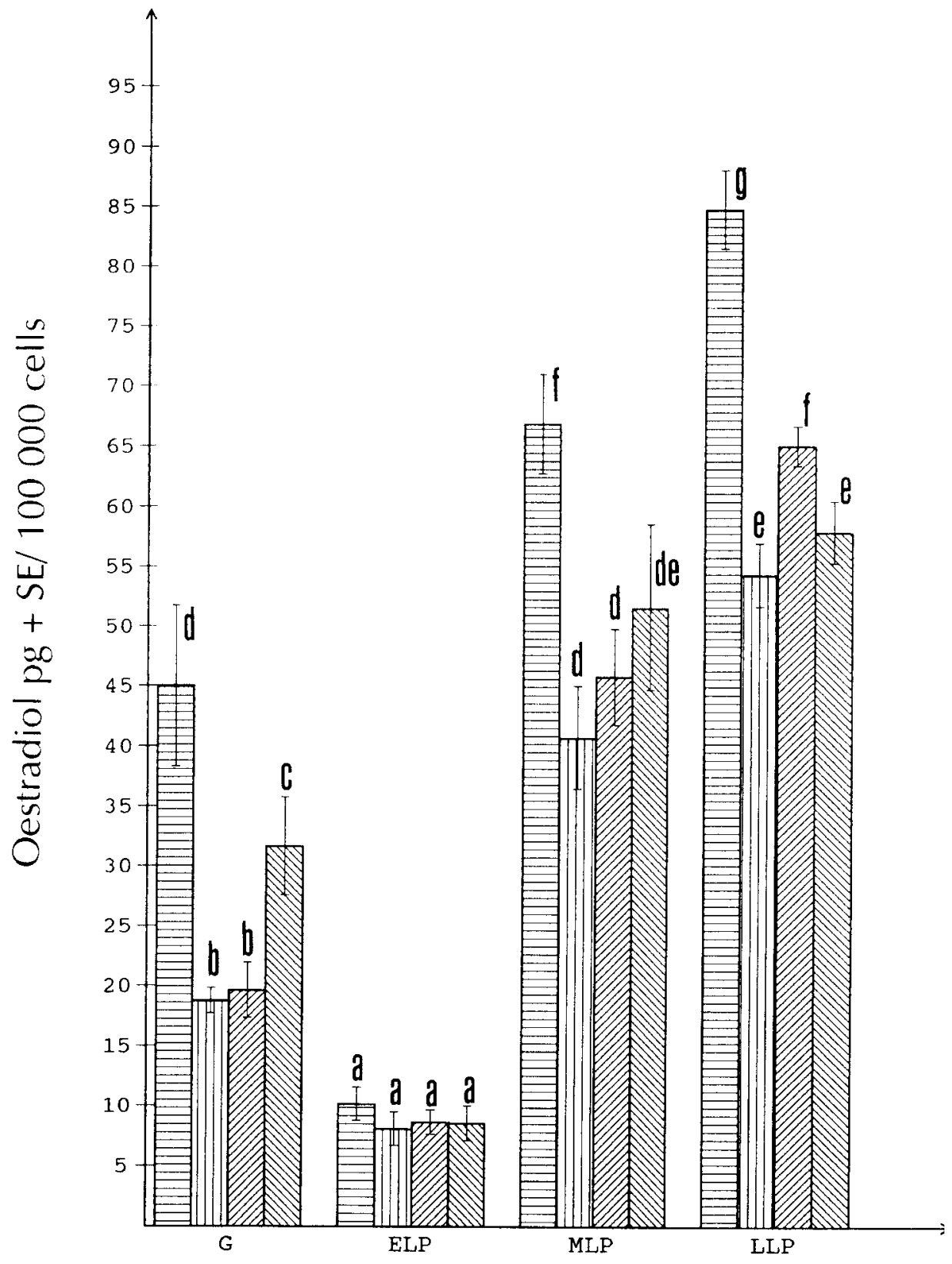

Fig 1. Effect of different doses of an aromatase inhibitor (AR) on basal oestradiol secretion by granulosa $(G)$ and luteal cells isolated from corpora lutea during early luteal phase (ELP), mid-luteal phase (MLP) and late luteal phase (LLP). Means without common superscripts (a-e) are significantly different $(P<0.05)$. C control 是; AR1 $1 \mu \mathrm{m}$ ili; AR2 $0.5 \mu \mathrm{M}$; AR3 $0.1 \mu \mathrm{M}$ CGS16949A 


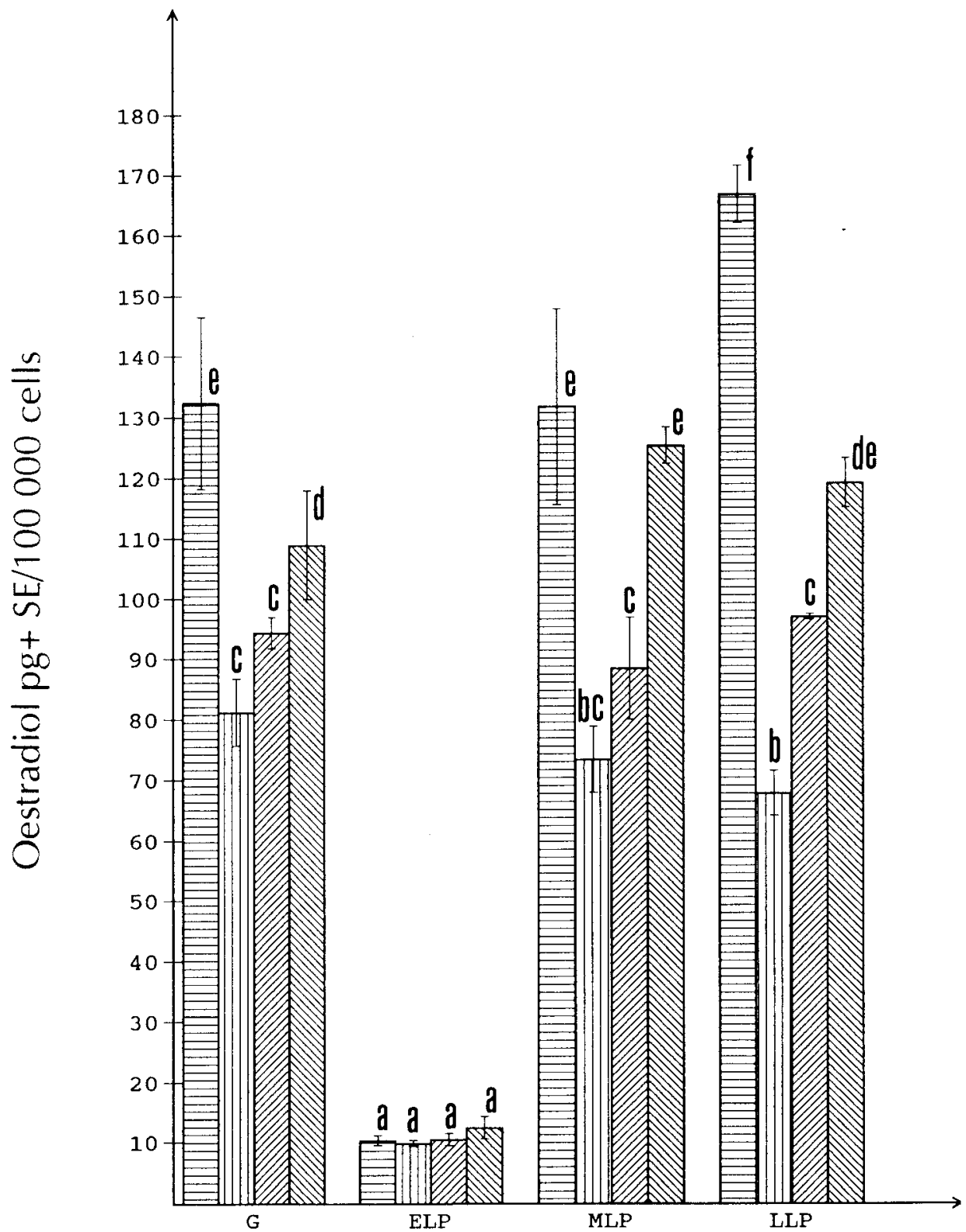

Fig 2. Effect of different doses of an aromatase inhibitor (AR) on oestradiol secretion by granulosa (G) cells and luteal cells isolated from corpora lutea during early luteal phase (ELP), mid-luteal phase (MLP) and late luteal phase (LLP) in testosterone-supplemented cultures. Means without common superscripts $(\mathrm{a}-\mathrm{C})$ are significantly different $(P<0.05)$. T $10 \mathrm{M}$ testosterone $\equiv ;$; T + AR1 $1 \mu \mathrm{M}$;in; T + AR2 $0.5 \mu \mathrm{M} \approx ; \mathrm{T}+\mathrm{AR} 30.1 \mu \mathrm{M}$ CGS16949A $\mathbb{N}$. 


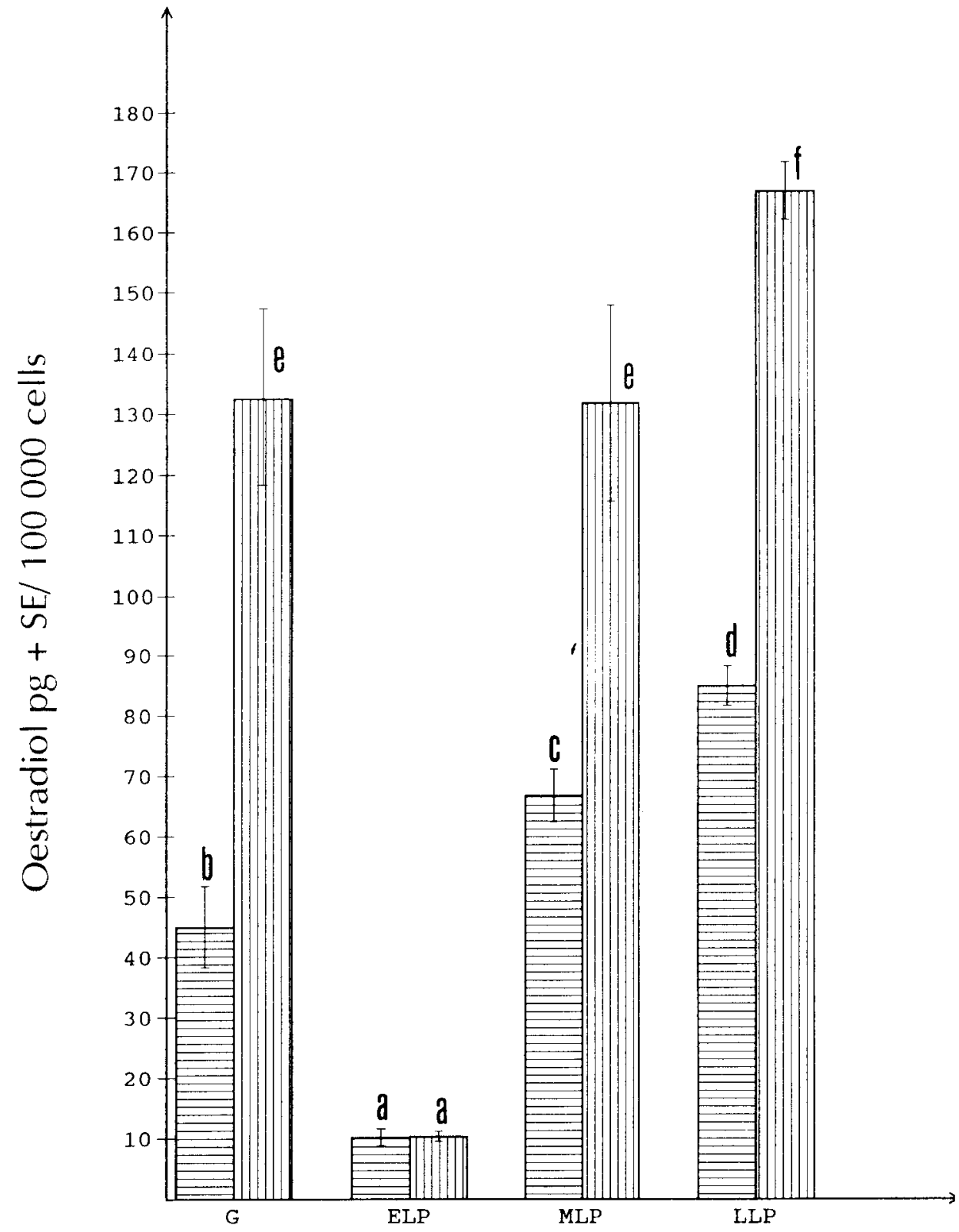

Fig 3. Oestradiol secretion by control and testosterone-supplemented cultures of granulosa (G) cells and luteal cells isolated from early developing (ELP), mature (MLP) and regressing (LLP) corpora lutea. All values are means SE. Means without common superscripts $(\mathrm{a}-\mathrm{c})$ are significantly different $(P<$ 0.05). C control 䒠; $\mathrm{T} 10 \mathrm{M}$ testosterone $\mathrm{Ifil}$. 


\section{Late luteal phase}

Adding testosterone to cultures of cells harvested in the late luteal phase produced a significant increase in oestradiol secretion (fig 3). Basal and testosterone-stimulated oestradiol secretion without inhibitor were higher in the late than in the early and midluteal phases (figs 1-3). Aromatase inhibitor added to the culture medium caused a decrease in both basal $(54.2,64.9,57.8$, $85.0 \mathrm{pg}$ oestradiol $/ 10^{5}$ cells for $1.0,0.5,0.1$, $0 \mu \mathrm{M}$ aromatase inhibitor) (fig 1 ) and testosterone-stimulated oestradiol secretion $(67.5$, 96.2, $118.8,158.6 \mathrm{pg}$ oestradiol/ $10^{5}$ cells for $1.0,0.5,0.1,0 \mu \mathrm{M}$ aromatase inhibitor, respectively) (fig 2 ).

\section{DISCUSSION}

The use of an aromatase inhibitor allowed us to further demonstrate aromatase activity in porcine corpora lutea and to show variations in this activity during the luteal phase. Recently, CGS 16949A has been introduced as a new nonsteroidal aromatase inhibitor. This compound has been shown to have high potency and selectivity towards the inhibition of the aromatase enzyme (Steele et al, 1987). The present study revealed no influence of the aromatase inhibitor on oestradiol secretion in luteal cells isolated during corpus luteum formation, which suggested a lack of active aromatase at this stage of the luteal phase. This is in agreement with the results of Yoshinaga-Hirabayashi et al (1990), who demonstrated high aromatization potential in granulosa cells of preovulatory follicles and a lack of immunoreactive aromatase immediately after ovulation in the rat. More recently, Guthrie et al (1994) observed that the aromatase mRNA concentration in pig follicular tissues decreased between the mid-follicular and late-follicular phases. This decrease in aromatase activity could be due to the inhibitory effect of prolactin upon the secretion of oestradiol in late follicular and early luteal cells (Stocklosowa et al, 1981; Gregoraszczuk, 1990,1991). This is supported by the observation of temporarily high levels of prolactin in the peripheral blood in pigs around the time of ovulation (Dusza and Tilton, 1990). Krasnow et al (1990) have also demonstrated that prolactin inhibits aromatase mRNA and oestradiol biosynthesis during the early stages of luteinization in rats.

Adding aromatase inhibitor to cultures of luteal cells that were isolated during midluteal phase caused a decrease in both basal and testosterone-stimulated oestradiol secretion. This supported the hypothesis that luteal cells from the mid-luteal phase have active aromatase. The results of our previous studies indicate that the oestradiol content in the homogenates of corpora lutea of the mid-luteal phase is very low in spite of a high androgen level (Gregoraszczuk 1992). A lack of active aromatase or the presence of an active aromatase inhibitory factor were then suggested. Gregoraszczuk (1994) demonstrated the simultaneous involvement of progesterone and testosterone in regulating oestradiol secretion during mid-luteal phase. An inhibitory effect of progesterone on testosterone-stimulated oestradiol secretion was observed in mid-luteal phase cell cultures. The high amount of progesterone found in the luteal tissue may play a role in the regulation of oestrogen production by suppressing the induction of aromatase synthesis or by inhibiting the activity of the enzyme complex. The present study clearly demonstrated that active aromatase was present at this stage of the luteal phase. Thus, the low oestradiol level observed at this stage was probably a consequence of the inhibitory effect of progesterone upon the activity of the enzyme complex.

The situation changes in regressing corpora lutea. A decrease in androgen and progesterone secretion as well as a significant 
increase in oestradiol secretion have been observed in vivo (Gregoraszczuk, 1992).

The present study confirmed the existence of aromatase activity in regressing corpora lutea since the aromatase inhibitor decreased the oestradiol release in control and testosterone-supplemented cells. Rosenkrans et al (1992) have suggested that catechol-oestrogens and oestradiol$17 \beta$ inhibit the synthesis of prostaglandin E2 and modify the PGE/PGF2 $\alpha$ ratio.

In conclusion, oestradiol secreted by the regressing corpora lutea may play an active role in the regulation of the oestrous cycle with a possible endocrine influence on gonadotropin secretion, a paracrine action on follicular growth, or an autocrine influence on the luteal activity.

\section{ACKNOWLEDGMENTS}

We would like to thank $S$ Stoklosowa for her revision of the manuscript and A Wojtusiak for the RIA. This work was supported by grant KBN PB $0243 / 53 / 92$ as well as by the SMA fund of the World Health Organization, Special Programme of Research, Development and Research Training in Human Reproduction.

\section{REFERENCES}

Bjersing $L$ (1967) On the morphology and endocrine function of granulosa cells in ovarian follicles and corpora lutea; Biochemical, histochemical and ultrastructural studies on the porcine ovary with special reference to steroid hormone synthesis. Acta Endocrinol Suppl 125, 1-23

Dusza L, Tilton JE (1990) Role of prolactin in the regulation of ovarian function in pigs. J Reprod Fertil 40, 30-45

Gregoraszczuk EL (1983) Steroid hormone release in cultures of pig corpus luteum and granulosa cells. Effect of LH, hCG, PRL and estradiol. Endocrinol Experim 17, 59-63

Gregoraszczuk EL (1990) Different response of porcine large and small luteal cells to PRL in terms of pro- gesterone and estradiol secretion in vitro. Clin Endocrinol 96, 234-237

Gregoraszczuk EL (1991) The interaction of testosterone and gonadotropins in stimulating estradiol and progesterone secretion by cultures of corpus luteum cells isolated from pigs in early and midluteal phase. Endocrinol Jpn 38, 229-237

Gregoraszczuk EL (1992) Interrelationship between steroid hormone secretion and morphological changes of porcine corpora lutea at various periods of luteal phase. Endocr Reg 26, 189-194

Gregoraszuk EL (1994) Is progesterone a modulator of luteal steroidogenesis in pig? A tissue culture approach. Folia Histochem Cytobiol 32, 31-33

Guthrie HD, Barber JA, Leighton JK, Hammond J (1994) Steroidogenic cytochrome P450 enzyme messenger ribonucleic acids and follicular fluid steroids in individual follicles during preovulatory maturation in the pig. Biol Reprod 51, 465-471

Krasnow JS, Hickey GJ, Richards JS (1990) Regulation of aromatase mRNA and estradiol biosynthesis in rat ovarian granulosa and luteal cells by prolactin. Mol Endocrinol 4, 13-21

Przala J, Wiesak T, Grazul A, Cieplinska E (1984) The effect of prolactin on estradiol $17 \beta$ - and testosterone plus 5-dihydrotestosterone secretion by porcine luteal cells in vitro. Clin Endocrinol 83, 334-343

Rodway RG, Dodson K, Watson J (1975) Steroid secretion by superfused porcine ovarian cells. Acta Endocrinol 199, 159-162

Rosenkrans CF, Paris BC, Davis DL, Milliken G (1992) Synthesis of prostaglandin by pig blastocysts cultured in medium containing estradiol or catechol estrogen. Prostaglandins 43, 309-319

Steele RE, Mellor LB, Sawyer WK, Wasvery JM, Browne $L J(1987)$ In vitro and in vivo studies demonstrating potent and selective estrogen inhibition with the nonsteroidal aromatase inhibitor CGS 16949A. Steroid $50,147-161$

Stoklosowa S, Gregoraszczk EL (1981) Do theca interna cells of the porcine ovarian follicle contribute to corpus luteum formation? Tissue culture approach using sorted ovarian cells. Cell Biol Intern Reports 5,770

Stoklosowa S, Gregoraszczuk EL, Channing CP (1982) Estrogen and progesterone secretion by isolated cultures porcine thecal and granulosa cells. Biol Reprod 26, 943-952

Yoshinaga-Hirabayashi T, Ishimura K, Fujita H, Kitawaki J, Osawa $Y(1990)$ Immunohistochemical localization of aromatase in immature rat ovaries treated with PMSG and hCG in pregnant rat ovaries. Histochemistry $93,223-228$ 